\title{
Pogranicze a badania politologiczne
}

\author{
Andrzej Chodubski ${ }^{1}$
}

Link do artykułu:

http://pogranicze.uni.opole.pl/biblioteka/docs/nr1/chodubski_nr1.pdf

Standard cytowania (APA):

Chodubski, A. (2013). Pogranicze a badania politologiczne. Pogranicze. Polish Borderlands

Studies, $n r$ 1, s. 68.

Kategoria „pogranicze” nie posiada w życiu politycznym jednoznacznej treści. W tradycyjnym rozumieniu postrzegana jest jako przestrzeń geograficzna, w pobliżu której przebiegają granice państwa, przestrzeń najdalej oddalona od centrum życia politycznego państwa. W przestrzeni tej przenikały się wartości różnych kultur, tworzyła się rzeczywistość wielokulturowa i etniczna, kształtował się wzór mieszkańca, charakteryzujący się m.in.: a) przedsiębiorczością i przystosowawczością do zmieniającej się rzeczywistości politycznej, b) odwagą w podejmowaniu indywidualnych decyzji, c) tolerancją wobec różnorodności postaw, zachowań, wartości.

Określana też mianem „kresów” była postrzegana jako przeciwległy biegun życia kulturowego, tj. „centrum”. Funkcjonowanie w tym usytuowaniu politycznym powodowało, że kresy utożsamiano społeczno-politycznie m.in. z: a) peryferyjnością, b) zacofaniem cywilizacyjnym, c) niską kulturą i świadomością polityczną, w tym międzynarodową.

W XIX w. pogranicze (kresy) stało się przedmiotem przewartościowujących ocen. Ważne miejsce zajęły one w myśli politycznej, co wiązało się ze stawianiem pytań o kształt terytorialny i ustrojowy państw, np. w romantycznej świadomości ujawniły się jako mityczny obszar polskości.
Współcześnie „pogranicze” jest szczególną rzeczywistością kulturowo-cywilizacyjną, w sytuacji globalizacji świata. Postrzegane jest ono jako siła, pomost integrujący narody i państwa. W przestrzeni europejskiej określa się je jako „euroregion”, zwraca się uwagę na budowę transgraniczności. Pogranicze staje się nośną kategorią w rzeczywistości zacierania się granic między różnymi podmiotami życia kulturowo-cywilizacyjnego.

$\mathrm{W}$ badaniach politologicznych, uprawianych interdyscyplinarnie, jak i wąskodyscyplinarnie kategoria ta stanowi przedmiot istotnego zainteresowania. Zajmuje ona istotne miejsce w rozpoznawaniu stosunków międzynarodowych, w tym bilateralnych między różnymi ich podmiotami, w badaniach europeistycznych, polityce społecznej, w tym np. w wymiarze ruchów migracyjnych, poziomu życia kulturowego, jak w badaniach stricte politologicznych, dotyczących funkcjonowania instytucji politycznych, kultury i świadomości politycznej. W badaniach politologicznych ujawnia się czytelnie perspektywa metodologiczna rozpoznawania istoty, funkcji, zadań pogranicza jako rzeczywistości politycznej. Nośne są w tym względzie zarówno teorie normatywne, jak i postmodernistyczne.

$\overline{1 \quad \text { Prof. zw. }}$ dr hab. Andrzej Chodubski: pracownik Zakładu Teorii Polityki Uniwersytetu Gdańskiego. 